\title{
A HISTOCHEMICAL PROPERTY OF THE OXYPHIL CELLS OF THE HUMAN PARATHYROID GLANDS
}

\author{
BY \\ A. C. CHRISTIE \\ From the Department of Pathology, the Royal Hospital for Women, Paddington, Sydney, Australia
}

(RECEIVED FOR PUBLICATION MAY 16, 1955)

It is the purpose of this communication to report a histochemical property of the "oxyphil" (so designated throughout this paper) or acidophil cells in human parathyroid glands, to re-examine the widely held view that such cells are merely involution forms of the principal cell, and to review the literature concerning their significance.

\section{Material and Methods}

Parathyroid glands were removed from routine necropsy cases, being mainly elderly subjects of both sexes. Gelatine-embedded blocks of formalin-fixed and post-chromed tissue were prepared and stained by Baker's (1946) acid-haematin technique for the histochemical detection of phopholipids. Near-by sections (although not strictly serial) were stained by haematoxylin and eosin. In each case a second parathyroid gland was treated as for Baker's pyridineextraction-acid-haematin test. It would have been preferable to bisect a single gland and treat one half by the first part and the other by the second part of Baker's test, but, so far, glands of sufficient size have not been available.

No attempt was made to make a quantitative study of the number of cells rich in phospholipid granules in each parathyroid gland examined.

\section{Brief Case Reports and Histological Observations}

In elderly subjects oxyphil cells are more numerous and are often grouped together to form small nodules. This has fortunately been the case in several necropsy specimens, and it is proposed to select two of these for special study.

As full morphological descriptions of the oxyphil cells have already been given by numerous workers, in particular Welsh (1898) and Gilmour (1939), it only remains to describe their appearances in sections stained by Baker's histochemical technique, a positive result with which has not previously been reported.

Case 1.-This was a male, aged 72 years, who developed uraemia and died in 1953 two months after total cystectomy for a carcinoma of the urinary bladder.
In one parathyroid of this case there is a small, $\frac{\hat{O}}{0}$ discrete nodule (Fig. 1), approximately $\frac{1}{2} \mathrm{~mm}$. in diameter, composed entirely of relatively large cells $\stackrel{f}{\phi}$ whose cytoplasm contains granules showing varying degrees of eosinophilia.

The pattern of pale and dark oxyphil cells within this nodule is identical with that depicted in Gilmour's (1939) colour plate (his Fig. 1) ; in addition, the histological appearances of each of these two types of oxyphil cell in this nodule conform to Gilmour's description of them. That this nodule is composed of oxyphil cells there can thus be no reasonable doubt. A near-by section (Fig. 2) taken from the same "run " of five or so frozen sections, and staine $\mathcal{O}$ or by Baker's acid-haematin test, that is, the first pat of his test, shows many polygonal cells containine numerous fine black granules evenly disperse throughout the cytoplasm of each cell. Some cells, often of crescentic shape with concave edges, are so heavily filled with granules that only in the thinnest parts of the sections can individual granules be discerned (Fig. 3). In sections approximately 7 or $8 \mu$ thick, as in Fig. 3, these cells appear as dense black masses, but examination of such cells in thinner sections indicates that this picture is due to a dense accumulation of the same fine discrete particles (vide infra). Such cells clearly correspond to the dark oxyphil cells. There are other cells, also depicted in Fig. 3, with almost colourless cytoplasm in which acid-haematin-positive fine granules are present, but only sparsely so. Such cells correspond to pale oxyphil cells. In these latter cells one or sometimes two bodies, corresponding to the description given by Gilmour (1939) of intracellular accumulations of pigment, can be seen. With the first part of the acidhaematin test these bodies always give a positively reacting rim of variable thickness, and usually the centres also appear darkly stained except for one or two, or even more, almost colourless spaces which correspond to the vacuoles also described by Gilmour. There are also cells with varying numbers of evenly dispersed fine granules : such are clearly intermediate forms which are either accumulating or being depleted of their positively reacting contents.

In the acid-haematin preparations nuclear detail is not well shown, but in near-by sections of the same 


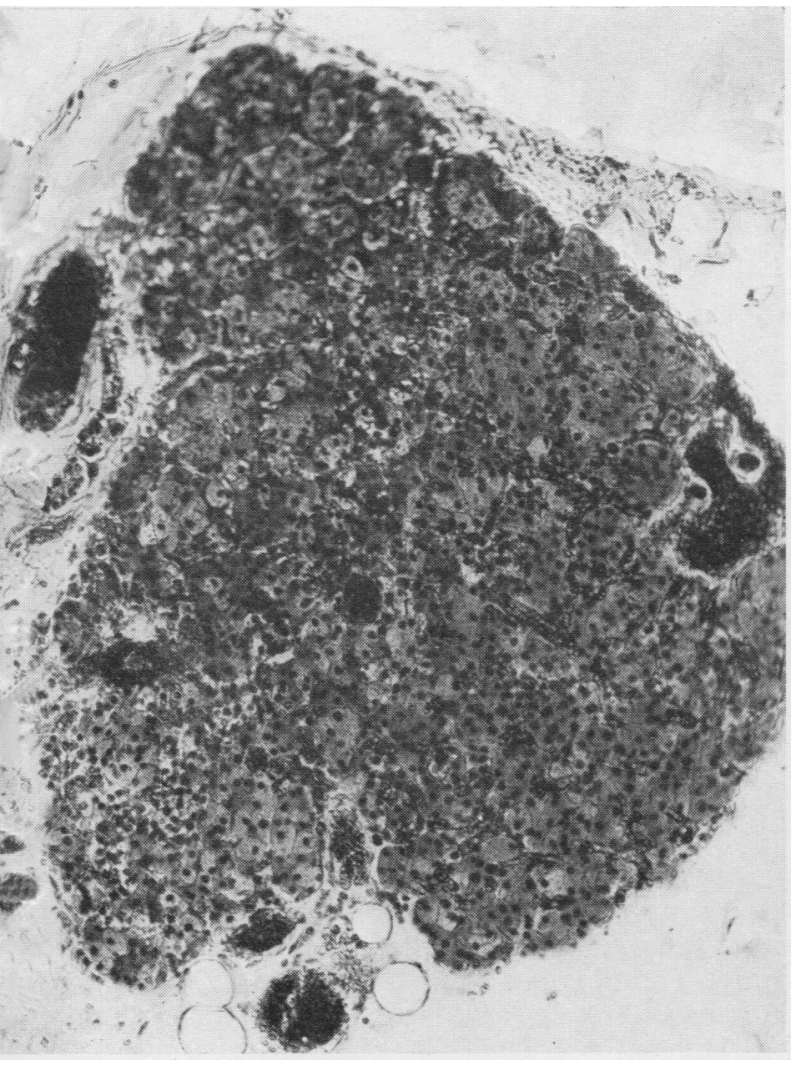

FrG. 1

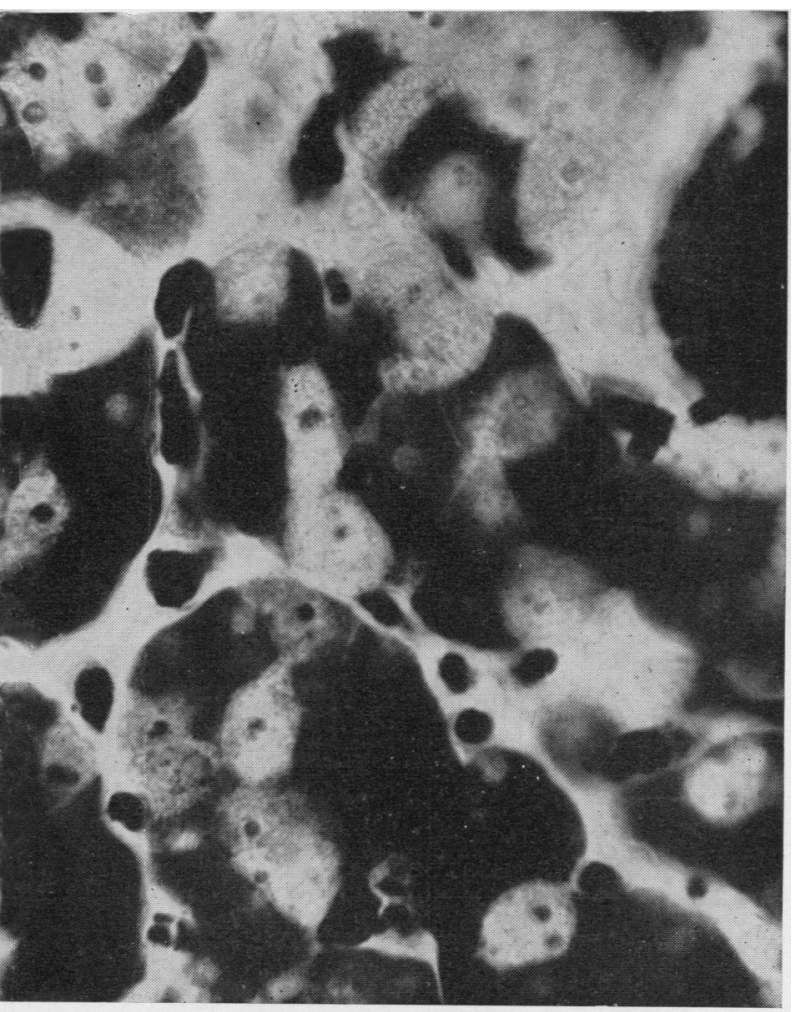

FIG. 2
Fic. 3

FIG. 1.-Case 1: On the right-hand side is seen in cross-section a discrete nodule of oxyphil cells, whilst on the left is glandular tissue composed almost entirely of principal cells. Haematoxylin-and-eosin-stained section from same gelatine block as Fig. 2. $\times 200$.

Fig. 2.-Case 1: On the right-hand side the nodule depicted in Fig. 1 is seen to consist of numerous dark oxyphil cells densely loaded with acid-haematin-positive granules, as well as cells either not so densely packed with or practically devoid of such granules. The mass of principal cells on the left is practically devoid of such granules: capillary channels containing heavily stained erythrocytes are clearly displayed. Baker's acid-haematin stain. $\times 200$. (Although taken from the same block, sections depicted in this and Fig. 1 are not serial.)

FIG. 3.-Case 1: A higher magnification of the area outlined in Fig. 2. The concave borders of the densely granulated cells are well shown. $\times 900$. 
nodule stained by haematoxylin and eosin such detail is excellent. Welsh's (1898) description of the oxyphil cell nucleus cannot be bettered, viz. :

"The nucleus is both relatively and absolutely smaller than the nucleus of the hyaline cell (he is here referring to what is now known as the 'principal' cell). In outline it [the nucleus of the oxyphil cell] is more nearly circular. Its chromatin is more densely arranged, so that no nuclear network can be detected, and the entire nuclear mass appears uniformly darkly stained."

When sections of this nodule are only lightly stained with haematoxylin and eosin some detail is apparent even in the densest nuclei, and pyknotic nuclei are very rarely seen. It is important to emphasize this point, because I consider that I have not yet seen cytological evidence to suggest that foci of oxyphil cells such as are present in this case and in that to be described below are, in fact, zones of cells undergoing involution. There is, however, in this nodule, which appears to consist entirely of oxyphil cells, considerable variation in nuclear size and chromatin content, and although the average size is, as observed by Welsh, smaller than that of the principal cell nucleus, there are all gradations from larger vesicular nuclei to smaller ones with fairly densely aggregated chromatin, but still possessing a definite pattern with numerous fine more or less evenly knotted chromatin threads.

A prominent feature of this nodule is its degree of vascularity, equal to that seen in parts of the gland containing principal cells.

In conclusion, the general histological appearance of this nodule is that of a gland, separate from the rest of the parathyroid tissue and composed of cells of similar type but in various stages of secretory activity. The degree of vascularity is also strong histological evidence of secretory activity rather than of inactivity and involution.

Case 2. - This was a female, aged 70 years, who succumbed to widespread lymphosarcoma with lymphatic leukaemia in 1953.

In one parathyroid there is a discrete oval nodule 1.0 by $0.5 \mathrm{~mm}$. in size (Fig. 4), which is composed entirely of oxyphil cells except for a very small focus of principal cells at one end, constituting less than one-fifth of the area of the nodule in the plane of the section depicted in Fig. 4. Although the haematoxylin-and-eosin-stained preparation shows some, but by no means marked, variation in the degree of eosinophilia of the cytoplasmic contents of these relatively large polygonal cells (Fig. 5), Baker's acid-haematin stain, applied to a section only a few microns deeper in the same gelatine block, shows cells which clearly correspond to pale and dark oxyphil cells respectively, as well as a considerable number of intermediate forms (Fig. 6). The dark, heavily granulated cells, like those described in Case 1, have concave borders, whereas the pale, less heavily granulated cells have not. Occasionally, when sections are examined under the $2 \mathrm{~mm}$. objective, very small intracytoplasmic bodies with a dark rim but colourless centre can be seen in some of the sparsely granulated cells : these almost certainly correspond to the minute vesicles described by Gilmour (1939).

This nodule, composed predominantly of oxyphil cells, is very well endowed with capillaries, many of which are filled with erythrocytes (Fig. 5), the degree of vascularity being certainly equal to, if not actually exceeding, that of the rest of the gland. There is also no cytological evidence of cellular degeneration or involution of the nodule as a whole.

In neither of the above cases could sections treated by the pyridine-extraction-acid-haematin part of Baker's test be seen to contain cells rich in positively reacting granules, hence the oxyphil cells give a true positive reaction with this test.

\section{Discussion}

Since the oxyphil cells were first clearly described by Welsh (1898)* little attention has been paid to them, although their existence as a cell type separate from the more numerous principal cells has been generally accepted (Gilmour, 1939 ; Maximow and Bloom, 1948 ; Nonidez and Windle, 1953); nevertheless some workers (Kurokawa, 1925; Hunter and Turnbull, 1931) have maintained that they are derived from the principal cell.

Oxyphil cells have not been described in domestic animals (Trautmann and Fiebiger, 1952) other than the ox (Levine, 1928). Smith and Copenhaver (1944) specifically stated that they do not occur in the dog, cat, or rat ; and Foster (1943, 1946) did not mention them in his studies on the mouse parathyroid. Levine recorded that oxyphil cells appear to be less frequent in steers than in cows, and noted that the isolated cells and clusters of cells in cows' glands have all the morphological and staining characteristics of the oxyphil cells in human material. He also considered that further evidence is found here for the contention that a physiological age factor operates in determining the presence of the oxyphil cells in these animals as it does in man.

There is also evidence to suggest that oxyphil cells are more numerous in women than in men. Gilmour (1939) observed that the number of such cells was comparatively very great in 22 out of 428 subjects which he studied: excluding cases of renal disease, the number was reduced to 15 , all of whom were females. The ages of the 22 subjects ranged from 41 to 76 and 10 were over 60 years of age. He concluded that "there appears, therefore, to be a definite relationship between excep-

- Sandström (1880) was the first worker to mention these cells, although he did not give a very detailed description of them. 


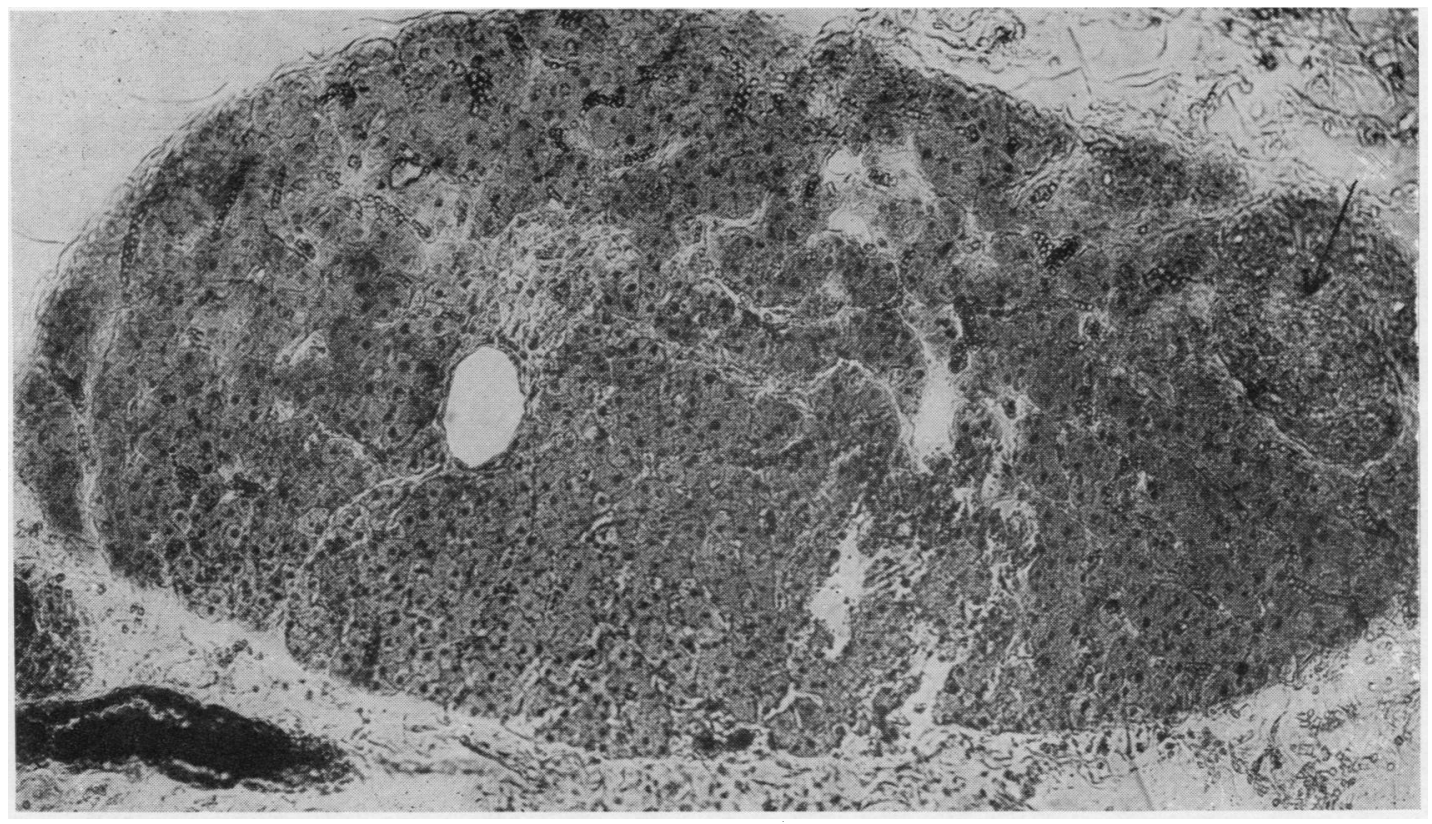

Fig. 4.-Case 2: A nodule composed predominantly of oxyphil cells except for a small, fairly well circumscribed nodule of principal cells, indicated by arrow. Haematoxylin and eosin. $\times 160$.

Fig. 5.-Case 2: A higher magnification of part of the area depicted in Fig. 4, showing a predominance of pale oxyphil cells. Haematoxylin and eosin. $\times 900$.
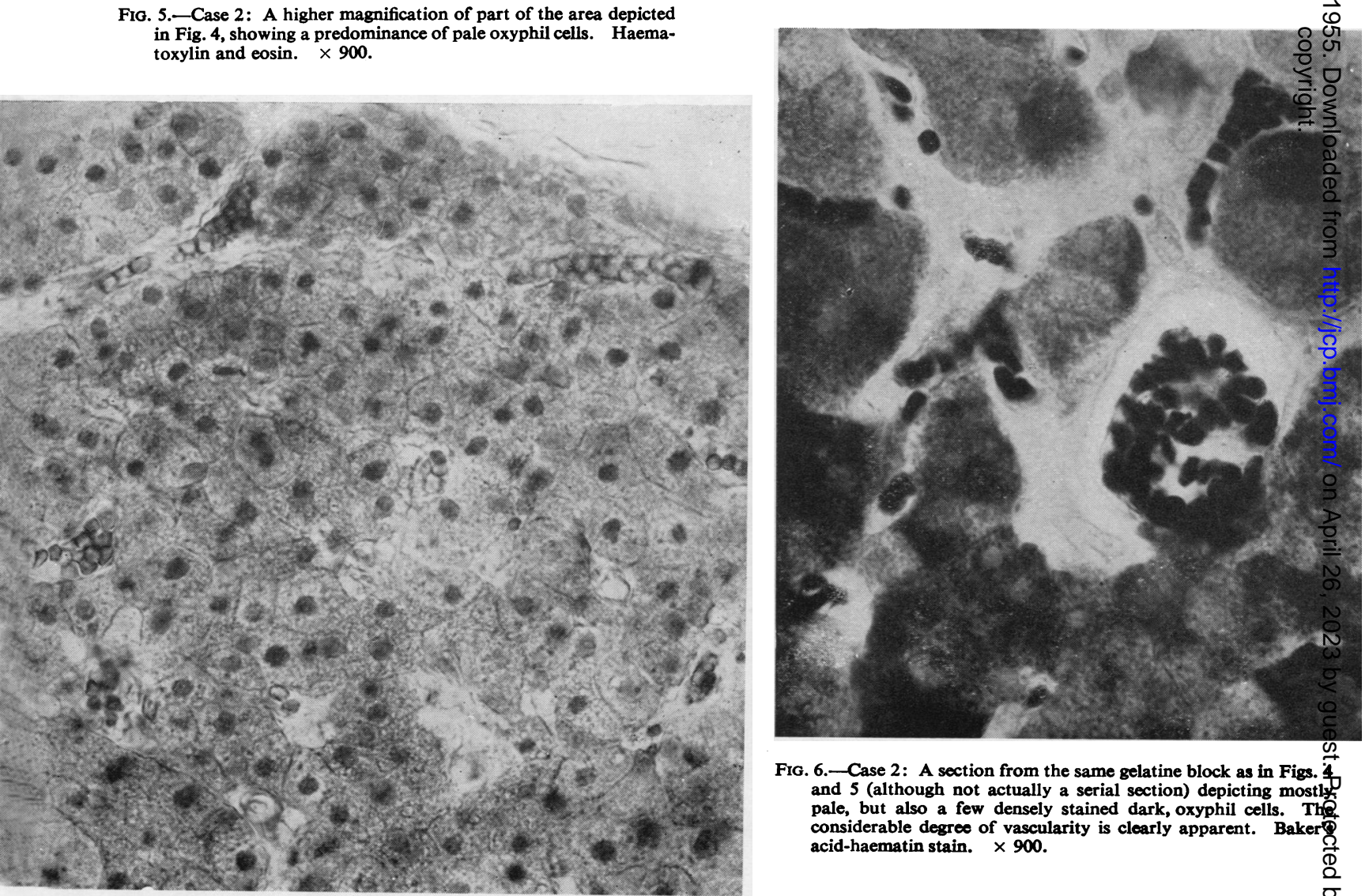

Fig. 6. - Case 2: A section from the same gelatine block as in Figs. 4 and 5 (although not actually a serial section) depicting mostly pale, but also a few densely stained dark, oxyphil cells. The considerable degree of vascularity is clearly apparent. Baker? acid-haematin stain. $\times 900$. 
tionally numerous oxyphil cells in the normal parathyroid and both age and sex."

It is interesting to note that, of the six cases of true oxyphil cell adenomata which the author has been able to collect from the literature, five have been in females.

Anderson (1953) also observed that these cells increase with age. As to the age at which they first appear there is some doubt: Erdheim (1901) considered about the tenth year, but Fischer (1911) saw them in a child aged 2 years, and Gilmour (1939) reported their presence in all subjects aged 3 years and over whom he examined.

Extensive histochemical studies of the parathyroid glands do not appear to have been undertaken. However, it is widely known that the principal cells are rich in glycogen, an observation first attributed to Petersen (1903). On the other hand, oxyphil cells are said to contain little or no glycogen (Gilmour, 1939 ; Stephenson and McNamara, 1948).

In 1946 Baker introduced a carefully standardized technique developed from the Smith-Dietrich test for the histochemical detection of lipins. In a later communication (1947) he claimed that this modification (the acid-haematin test), controlled by his pyridine-extraction test, allows histochemical recognition of phospholipids. This was confirmed by Cain (1947) while working in Baker's laboratory. Casselman (1952) applied this technique in vitro to certain synthetic enantiomeric $\alpha$-phosphatidic acids, phospholipids, and related compounds, and to highly purified, natural lipin fractions, as well as to an additional 123 other substances: only phospholipids and certain phosphatidic acids give positive results.

Baker's histochemical test gives a positive reaction for phospholipids in the case of the pituitary acidophil cells in rats (Rennels, 1953), and also in the guinea-pig and man (unpublished work).

The resemblance between the pituitary acidophil cells and the parathyroid oxyphil cells was first emphasized as far back as 1898 by Welsh, who referred to it as "striking," and more recently by Maximow and Bloom (1948). It is now further enhanced by the fact that they both react similarly with Baker's test. This certainly does not imply exact chemical identity, but does suggest the possibility that the granules are probably composed, either in part or wholly, of substances belonging to a similar group of chemical compounds. (This observation may also prove of value in the chemical extraction and identification of the substances within these cells.)
When visual comparisons are made of the relative size of the positively reacting granules in the pituitary acidophil, parathyroid oxyphil, and argentaffin (Kultschitzky) cells in human material, it is apparent that in the former two they are of approximately the same size and considerably larger than in the last-mentioned. The fine granules of the argentaffin cell also give a positive reaction with Baker's stain (Christie, 1954).

As regards the function of the oxyphil cells nothing is known. Castleman and Mallory (1935) contended that "... it can fairly be said that histological evidence fails to support the concept of the elaboration of the parathyroid hormone by the oxyphil cells." Black and Ackerman (1950) and Nonidez and Windle (1953) also contended that the principal cells appear to be responsible for secreting the parathyroid hormone.

Some workers have considered that the oxyphil cells are likely to be involution forms-for example, Castleman and Mallory (1935) stated that "the frequency of these cells in tumours, even in young people, their absence in hyperplasias, their increase under normal conditions in old age, all point towards an involution phenomenon." All the same, they did admit that the possibility of another function, unconnected with calcium metabolism, could not be ruled out, although they found no evidence for it.

A detailed histological study of the parathyroid glands in both the cases reported above as well as in many other glands has failed to convince the writer that there is any evidence of a cytological nature to suggest that oxyphil cell collections (large or small) are foci of cell degeneration or involution ; in particular, the marked degree of vascularity throughout such zones, with numerous open capillaries, is evidence to the contrary. Such vascularity has been observed in the case of other actively secreting endocrine organs as, for example, the islets of Langerhans and the pituitary gland.

Furthermore, Baker's histochemical technique provides yet additional evidence of similarity with the pituitary acidophil cells whose histological significance as an endocrine unit is beyond doubt.

Excluding neoplasms, there are four well recognized conditions in which hyperplastic parathyroid glands are encountered, namely, rickets (or osteomalacia), pregnancy, renal insufficiency of the type associated with phosphate retention, and calcium deprivation (Albright and Reifenstein, 1948). Parathyroid hyperplasia has also been found in association with extensive skeletal tumours such as multiple myeloma and metastatic carcinoma (Ben-Asher, 1939). The histology of the para- 
thyroid glands in pregnancy has apparently not been studied in any detail.

Not all workers agree on the effects of renal disease on the number of oxyphil cells, that is, whether they increase or decrease. Fritz and Brines (1951) examined the parathyroids of 61 cases of bilateral renal disease; while finding a definite increase in total glandular weight as compared with 76 control cases without renal disease, they observed no increase in the number of oxyphil cells. On the other hand, Castleman and Mallory (1937) examined the glands in 29 cases of chronic renal insufficiency and found that the oxyphil cells are always greatly increased in number. In his monograph (1947) Gilmour dealt with the parathyroid glands in renal disease and referred to several cases in which oxyphil cells were numerous, being particularly so in two cases, females aged 40 and 60 years respectively. Black and Ackerman (1950) considered that oxyphil cell adenomata may appear in patients with longstanding renal disease, and reported two such cases. One of these was a female, aged 59 years, suffering from osteoporosis of the vertebrae, rheumatoid arthritis, hypertensive heart disease, and nephritis, who was submitted to operation for exploration of the parathyroids, all of which were enlarged to about twice their normal size with the exception of the left, which was considerably larger ( 3 by 3 by $1.3 \mathrm{~cm}$.) and composed entirely of oxyphil cells. Following removal of this oxyphil cell adenoma there were no significant changes in the serum calcium, phosphorus, or alkaline phosphatase values - observations which they considered strong evidence that the oxyphil cell adenoma was not secreting parathormone.

The second relevant case described by Black and Ackerman (their Case 13) was a female aged 66 years, who gave a somewhat similar history and comparable biochemical findings as well as showing evidence of renal calculi and osteoporosis. At necropsy severe renal damage was found and death was attributed to this cause, but in addition a parathyroid oxyphil cell adenoma, measuring 4.3 by 2.2 by $1.9 \mathrm{~cm}$., was found.

It now remains to discuss the rarely occurring tumours composed either entirely of, or with a predominance of, oxyphil cells. Norris (1947) collected 322 cases of parathyroid adenoma from the literature over 43 years (1903-45 inclusive): of these, only four were classified as oxyphil-cell adenomata (Hunter and Turnbull, 1931; Cope, 1944 ; McQuillan, 1938 ; Norris, 1946). Of these, only the latter two workers' case reports show con- vincing photomicrographic evidence of typical oxyphil cells, and neither case showed evidence of osteitis fibrosa or the other stigmata associated with principal cell tumours.

McQuillan's case-a solitary tumour measuring 9 by $6 \mathrm{~cm}$. in a female aged 46 years-is particularly interesting in that the tumour appears to have arisen following childbirth and has since regularly become enlarged during the menses. Norris's case was a female, aged 23 years, who had a solitary oxyphil adenoma measuring $3.5 \mathrm{~cm}$. in diameter. Keynes (1936) and Hadfield and Rogers (1932) have each reported typical oxyphil cell tumours, the former worker's case being a female aged 50 years, in which the tumour weighed $18 \mathrm{~g}$.; and the latter's case, a female aged 58 years, in which the tumour weighed $52 \mathrm{~g}$. Once again skeletal and other evidence of hyperparathyroidism was absent in each case.

There have been several reports of cases with pluriglandular adenomatosis involving the pituitary and parathyroid glands, and sometimes the pancreas and adrenals as well. The pituitary tumour has consisted of either chromophobe cells (Lloyd, 1929 ; Kalbfleisch, 1937 ; Underdahl, Woolner, and Black, 1953, Case 6; Marshall and Sloper, 1954) or acidophil cells (Cushing and Davidoff, 1927, Case 3). Of Cushing and Davidoff's (1927) four cases of acromegaly of differing clinical types, only Case 3, a male aged 34 years, described as "typical acromegaly of circa 15 years' duration," showed parathyroid hyperplasia, and then of slight degree-only two glands were identified, the larger being $9 \mathrm{~mm}$. in diameter. Each gland contained small adenomata consisting predominantly of principal cells, although the larger did contain a small peripheral zone of oxyphil cells.

Likewise in Lloyd's (1929) case-a 22-year-old female showing, at necropsy, a large pituitary chromophobe adenoma, adenoma-like enlargements of the islands of Langerhans, parathyroid glands and adrenals - the principal cell predominated in two enlarged parathyroid glands (the third gland located was of normal size).

Of three cases of pluriglandular adenomatosis described by Kalbfleisch (1937), in the third, a male aged 23 years, there was, in addition to a malignant tumour of the anterior lobe of the pituitary gland and an adenoma of the pancreas, slight hyperplasia of the parathyroid glands, particularly the left lower one (found embedded in the thymus). The principal cell predominated in the hyperplastic glands, but a few oxyphil cells were also present in all four glands. (There was 
clinical evidence of calcium deficiency in the skeleton.)

Also in Shelburne and McLaughlin's (1945) case -a seaman aged 26 years, with radiological and clinical evidence of a pituitary tumour and surgically removed solitary adenomata of both the pancreatic islets of Langerhans and parathyroid glands respectively-the predominant cell type in the latter, although not stated, was presumably the principal cell, as there was clinical evidence of hyperparathyroidism with a high serum calcium level and recurrent renal calculi.

Willis (1948) reported an interesting finding in an obese woman of 55 years who died the day after operation for multiple large uterine myomas. Necropsy disclosed a yellowish ovoid tumour measuring 2.5 by $1.5 \mathrm{~cm}$. in the position of one of the inferior parathyroids. Microscopically it was a parathyroid adenoma, composed mainly of large, solid, liver-like oxyphil cells, but also with areas of small cuboidal cells in acinus-like clusters and of vacuolated clear cells. In addition, there was a meningioma, $4 \mathrm{~cm}$. in diameter, in the cerebello-pontine angle and multiple cortical adenomata of both adrenal glands. (Willis remarked that the multiplicity of tumours in this case was noteworthy.)

Underdahl et al. (1953) reviewed the world literature relating to such multiple endocrine adenomata for the period 1903-51. They added seven cases of their own. One of these, a very obese male, aged 28 years, had a chromophobecell pituitary tumour, multiple parathyroid and islet-cell tumours, adenomatous nodules of adrenal cortices, and "diffuse polyposis of the gastric mucosa with giant rugae characteristic of Menetrier's disease." In the three enlarged parathyroids there were four small adenomata, one, of the order of $0.5 \mathrm{~cm}$. in diameter as measured from the photograph, being composed of oxyphil cells. It is interesting to note that both Willis's and this case were reported as being obese, the latter (Underdahl's) being particularly so (307 lb.).

More recently Marshall and Sloper (1954) reported the case of a male aged 40 years with a chromophobe-cell pituitary adenoma, islet cell adenomata of the pancreas, multiple adrenal adenomata, and a small solitary parathyroid tumour $(1.7$ by $0.8 \mathrm{~cm}$.) consisting predominantly of chief and water-clear cells except for one lobule composed entirely of oxyphil cells.

It thus appears that oxyphil-cell adenomata do occur but rarely, and are not associated with skeletal or other changes characteristic of hyperparathyroidism. Also when associated with other endocrine tumours they are usually very small and do not constitute the chief cell component of the enlarged organs, Willis's case being an exception.

Of the six cases of predominantly, or completely, oxyphil-cell adenomata unassociated with renal disease referred to above, five occurred in females, and one, that of Underdahl et al. (1953), in a male. The latter's oxyphil-cell tumour was, as mentioned above, only small $(0.5 \mathrm{~cm}$. in diameter) and associated with larger adenomata of other endocrine glands ; consequently solitary tumours of moderate or large size involving these cells have all been in females.

As there is such a close histological similarity between the pituitary acidophil cells and the parathyroid oxyphil cells the possibility exists that they may have a similar function, and that adenomata $N$ of the latter might be responsible for a clinical 은 syndrome resembling acromegaly either in its classical or " fugitive" form (Bailey and Cushing, $z$ 1928). However, there is no evidence from the above-mentioned case reports that such is the case : in fact the few case reports of solitary oxyphil cell tumours referred to earlier have been unassociated with any clinical syndrome. If such tumours are secreting an excess of a hormone, differef from parathormone, which has definite clinica. effects both when deficient and in excess, then appears that such an increase has no adverse clinical effect. (Such is the case with an interstitial cell tumour of the testis in an adult male.)

The histochemical stain described above is considered a valuable aid in histological technique to distinguish more clearly between principal cells of various types on the one hand and true oxyphil cells on the other. It may help in the further study of tumours composed of Castleman and Mallory's (1935) “transition oxyphil " cells.

\section{Summary}

Oxyphil cells in human parathyroid glands give 음 a positive reaction with Baker's acid-haematin $\rightarrow$ histochemical test for phospholipids, thus revealing a further resemblance between these cells and $N$ the acidophil cells of the pituitary gland.

Histological evidence is adduced to indicate that $\stackrel{N}{\circ}$ there is no reason to believe that the oxyphil cells $\underset{\omega}{N}$ are degenerate or involution forms of the principal cell.

Various clinical conditions in which oxyphil cell hyperplasia has been reported are briefly referred $\stackrel{\mathcal{P}}{\rightarrow}$ to. There is no apparent association with acro- $\frac{T}{0}$ megaly either in its classical form or Bailey and $\stackrel{\vec{\Phi}}{\circ}$ Cushing's (1928) "fugitive" types. When the $\stackrel{\square}{\Phi}$ 
parathyroid is involved in pluriglandular adenomatosis, the lesion is predominantly a principal cell hyperplasia.

A search of the literature has indicated that the rare tumour composed predominantly of oxyphil cells occurs mainly in females. It does not give rise to the clinical manifestations of osteitis fibrosa.

It is considered that a complete reinvestigation of these cells in normal healthy subjects of both sexes of all ages, in various disease states, and especially in pregnancy (both normal and abnormal) should be undertaken. A constant search should also be made for further examples of oxyphil-cell adenomata in life as well as at necropsy. In the latter instance a thorough search should be made for tumours or other lesions elsewhere, particularly in the light of the findings reported by Willis (1948)

I wish to thank Mr. Alan Hunt and Dr. P. Thompson Hancock, of the Royal Marsden Hospital, London, for permission to use material from their Cases 1 and 2 respectively. My thanks are due to Mr. F. E. Speed, of the Chester Beatty Research Institute, London, for the photomicrographs.

\section{REFERENCES}

Albright, F., and Reifenstein, E. C. (1948). The Parathyroid Glands and Metabolic Bone Disease, p. 46. Williams and Wilkins, Baltimore.

Anderson, W. A. D. (1953). Pathology, 2nd ed., edited by W. A. D. Anderson. Kimpton, London.

Bailey, P., and Cushing, H. (1928). Amer. J. Path., 4, 545.

Baker, J. R. (1946). Quart. J. micr. Sci., 87, 441.

- (1947). Ibid., 88, 463.

Ben-Asher, S. (1939). J. Lab. clin. Med., 24, 709.
Black, B. K., and Ackerman, L. V. (1950). Cancer, 3, 415.

Cain, A. J. (1947). Quart. J. micr. Sci., 88, 467.

Casselman, W. G. B. (1952). Ibid., 93, 381.

Castleman, B., and Mallory, T. B. (1935). Amer. J. Path., 11, 1.

- (1937). Ibid., 13, 553.

Christie, A. C. (1954). Nature, Lond., 173, 589.

Cope, O. (1944). Surgery, 16, 273.

Cushing, H., and Davidoff, L. M. (1927). The Pathological Findings in Four Autopsied Cases of Acromegaly with a Discussion of Their Significance. Monographs of the Rockefeller Institute for Significance. Monographs
Medical Research, No. 22.

Erdheim, J. (1901). Wien. klin. Wschr., 14, 974.

Fischer, E. (1911). Arch. Anat. Physiol., Lpz. (Anat. abt.), p. 133.

Foster, C. L. (1943). J. Endocr., 3, 244.

(1946). J. Anat., Lond., 80, 171

Fritz, G. E., and Brines, O. A. (1951). Amer. J. Path., 27, 265.

Gilmour, J.' R. (1939). J. Path. Bact., 48, 187.

(1947). The Parathyroid Glands and Skeleton in Renal Disease. Oxford Univ. Press, London.

Hadfield, G., and Rogers, H. (1932). J. Path. Bact., 35, 259.

Hunter, D., and Turnbull, H. M. (1931). Brit. J. Surg., 19, 203.

Kalbfleisch, H. H. (1937). Frankfurt. Z. Path., 50, 462.

Keynes, G. (1936). Brit. J. Surg., 24, 403.

Kurokawa, K. (1925). Japan med. World, 5, 241.

Levine, M. (1928). Anat. Rec., 39, 293.

Lloyd, P. C. (1929). Bull. Johns Hopk. Hosp., 45, 1.

McQuillan, A. S. (1938). Ann. Surg., 108, 464.

Marshall, A. H. E., and Sloper, J. C. (1954). J. Path. Bact., 68, 225.

Maximow, A. A., and Bloom, W. (1948). A Textbook of Histology, 5th ed. Saunders. Philadelphia.

Nonidez, J. F., and Windle, W. F. (1953). Textbook of Histology, 2nd ed. McGraw-Hill, New York.

Norris, E. H. (1946). Arch. Path., Chicago, 42, 261. (1947). Int. Abstr. Surg., 84, 1.

Petersen, H. (1903). Virchows Arch. path. Anat., 174, 413.

Rennels, E. G. (1953). Anat. Rec., 115, 659.

Sandström, I. (1880). Upsala LäkFören. Förh. (1879-80), 15, 441 ; extract in Schmidts Jb. (1880), 187, 114.

Shelburne, S. A., and McLaughlin, C.'W. (1945). J. clin. Endocr., $\mathbf{5}, \mathbf{2 3 2}$.

Smith, P. E., and Copenhaver, W. M. (1944). Bailey's Textbook of Histology, 11th ed., p. 665. Williams and Wilkins, Baltimore

Stephenson, H. U., and McNamara, W. L. (1948). Amer. J. med. Sci., $215,381$.

Trautmann, A., and Fiebiger, J. (1952). Fundamentals of the Histology of Domestic Animals, p. 140. Authorised translation by Habel, R. E., and Biberstein, E. L. Baillière, Tindall \& Cox, London.

Underdahl, L. O., Woolner, L. B., and Black, B. M. (1953). J. clin. Endocr.. 13, 20

Welsh, D. A. (1898). J. Anat., Lond., 32, 380.

Willis, R. A. (1948). Pathology of Tumours, 1st ed., p. 637 Butterworth, London. 